\title{
Possibilidades de estudo da alimentação egípcia antiga
}

\section{Possibilities of the study of ancient Egyptian food}

Cintia Gama ${ }^{1}$

O estudo de culturas passadas, principalmente no que concerne ao cotidiano e às práticas mais habituais a uma determinada sociedade em períodos históricos recuados, apresenta diversas dificuldades devido à falta de documentação escrita que trate de padrões tão comuns a uma coletividade. Tendo em vista as dificuldades do estudo de padrões cotidianos, as pesquisas acerca da alimentação na antiguidade não escapam a essas questões, especialmente no que concerne às fontes tanto epigráficas quanto arqueológicas bem como a uma metodologia de estudo. Deste modo, tendo em vista tanto questões metodológicas quanto documentais, nossa breve apresentação tem como objetivo mostrar como a arqueologia, as fontes epigráficas e escritas têm auxiliado na compreensão dos padrões alimentares egípcios antigos e na relação desse povo com seus alimentos. Apresentaremos as diversas fontes para o estudo dos padrões alimentares dessa população, bem como faremos uma análise dos textos funerários associados à alimentação, mais precisamente os Textos dos Caixões, do Médio Império (2.000-1580 a.C.), bem como a apresentação de fontes arqueológicas que corroboram ou não com os textos, passando por uma breve revisão bibliográfica do tema que se encontra bastante em voga na atualidade.

Assim, trataremos também da questão do excesso de fontes acerca do cotidiano egípcio, o que, na contramão do estudo das culturas da antiguidade, pode também nos induzir ao erro.

Nossa apresentação terá, dessa maneira, o intuito de discutir abordagens metodológicas, bem como as fontes para o estudo da alimentação do período faraônico, colocando, assim, a egiptologia como um campo fértil para o conhecimento dos meios de produção e consumo de alimentos no campo de estudos da história/arqueologia alimentar.

Palavras-chave: egiptologia; alimentação; fontes; arqueologia; epigrafia.

Keywords: Egyptology; food; sources; archaeology; epigraphy.

1 Pós-doutoranda pelo Museu Nacional da Universidade Federal do Rio de Janeiro, pesquisadora da École Pratique des Hautes Études, coordenadora do curso de gastronomia do Centro Universitário das Faculdades Metropolitanas Unidas (FMU). 